\title{
$\longrightarrow$ \\ Border Violence, Democracy, and the Museum
}

\author{
Simon Knell
}

ABSTRACT: This article is a re-edited version of the opening prelude to the author's The Museum's Borders: On the Challenge of Knowing and Remembering Well (Routledge, 2021). Based on reportage concerning the Windrush scandal, this article makes the case for the museum to be understood as an autonomous institution critical to knowledge-based democracies. The scandal, exposed in 2018, was the result of the British Government's "hostile environment," a brutal approach to immigration that ensnared historic migrants to Britain from the Caribbean. Resulting in state violence against Black British citizens, it revealed the degree to which Britain remained mired in institutional racism. Museums, libraries, and other cultural institutions played a critical role in recovering and asserting the history and legitimacy of these people.

KEYWORDS: Britain, democracy, library, museum, racism, violence, Windrush

In 2018, the Higgins-a large, modern, multidisciplinary, town museum and art gallery in Bedford in the English Midlands-was one of several institutions in Britain to commemorate the seventieth anniversary of the first arrival of Caribbean migrants. Known as "the Windrush generation," they had been drawn to the "mother country" by new equalities provided by the British Nationality Act (1948). While a number of British public sector industries would later recruit directly from the Caribbean, this migration was born in Jamaica in the aspirations of those who saw, in Britain and the new act, opportunities for a better life (Brinkhurst-Cuff 2018). The 2018 commemorations, however, were framed by an alternative narrative: Britain reaching out to her colonies for the labor for her reconstruction after World War II (British Library 2018a; McDowell 2018). While this act of meritorious re-narration was meant as a gift of recognition, it had the advantage for some of its authors of permitting a border to be erected between this and more recent migrations from the low wage economies of Central and Eastern Europe, which were then being used in nativist anti-immigration discourses to disrupt mainstream British politics. In fact, there was no difference between Caribbean migrants arriving in the 1940s and 1950s and those arriving from Romania, Bulgaria and Poland sixty years later. Both communities took advantage of a legal right of entry and both saw similar opportunities. Both were met with a negative response from some in the political establishment and press. Both made similar contributions and both endured violence and abuse. Both were seen, in their day, as transgressing national and cultural borders, as being "visibly different." 


\section{The Hostile Environment and the Windrush Scandal}

It might be thought that, after seventy years, the Windrush generation would be fully inducted into a modern sense of Britishness that was partly Black and of Caribbean heritage. Those who had arrived as children were now British pensioners, having worked their entire lives in the country. The culture they had introduced into Britain was now deeply imbedded in towns and cities across the country. Surely, no one could doubt that these people were British. In government circles, however, there was far less certainty, and at that very moment when these Windrush anniversary exhibitions were meant to introduce a period of recognition, reflection, and celebration, they were instead given unexpected poignancy as the result of an emerging national scandal. For it was only then that the wider British public first became fully aware of the devastating consequences for this historic generation of migrants of former Home Secretary, and later Prime Minister, Theresa May's "hostile environment," which sought to apply brutal and inhumane measures to stem the tide of immigration (Kirkup and Winnett 2012; Hill 2017). May had been home secretary under David Cameron, who had risen to power using rhetoric about mass illegal migration and failed multiculturalism (Cameron 2011a, 2011b). He argued that there had been too much timidity in these areas, but critics accused him of legitimizing the rhetoric of far-right groups like the English Defence League (Liberty 2019). This permitted May to pursue a policy of zero tolerance, driving compassion out of the immigration system: "The ludicrous former position was that UKBA [UK Border Agency] had to examine proactively every case for compassionate factors before they could remove someone" (May quoted in Williams 2020: 67). The government deployed "Go Home" vans to patrol neighborhoods where there were migrant populations. Seeking to intimidate an already vulnerable group, these displayed fictitious statistics: "In the UK illegally? Go home or face arrest. 106 arrests last week in your area” (Travis 2013; Kentish 2018).

This crackdown on migration was not simply an assault on recent migrants; it questioned the status of anyone who had arrived in Britain as a migrant, no matter how long ago and regardless of their settled status (Taylor 2018). They now found themselves subjected to investigations under the recently introduced Immigration Acts of 2014 and 2016, which turned hospitals, universities, workplaces, rented accommodation, and so on, into border posts. These policies had been introduced despite the Home Office being cognizant of the fact that half a million settled migrants in Britain would have difficulty proving their status. Indeed, some in government argued that these measures were unworkable and inappropriate (Williams 2020: 210). British citizens who had arrived as Windrush children perhaps fifty years before now found themselves trapped in May's hostile environment, where they were denied the right to work, healthcare, shelter, and social security (Gentleman 2018a, 2018b). Experiencing the full effects of Home Office performance targets for deportation, these legal British citizens were detained and deported, and driven into ill health, poverty, and suicide (Public Accounts Committee 2019; BBC 2018). The "Windrush scandal," as it became known, revealed how pervasively, subtly, and easily borders can be erected within a society and yet remain invisible to a wider population (Gentleman 2019b) (see Figure 1).

In 2016, in the chaotic aftermath of the Brexit vote, May had launched her premiership using rhetoric about compassionate one-nation conservatism, which came as a relief after the Cameron government's austerity-led assault on the most disadvantaged in society. In 2018, however, when the Windrush scandal broke and with the hostile environment still in place, her message of empathy took on the appearance of a form of doublespeak behind which the bureaucratic machinery of the state was actively threading borders through British society in ways never 


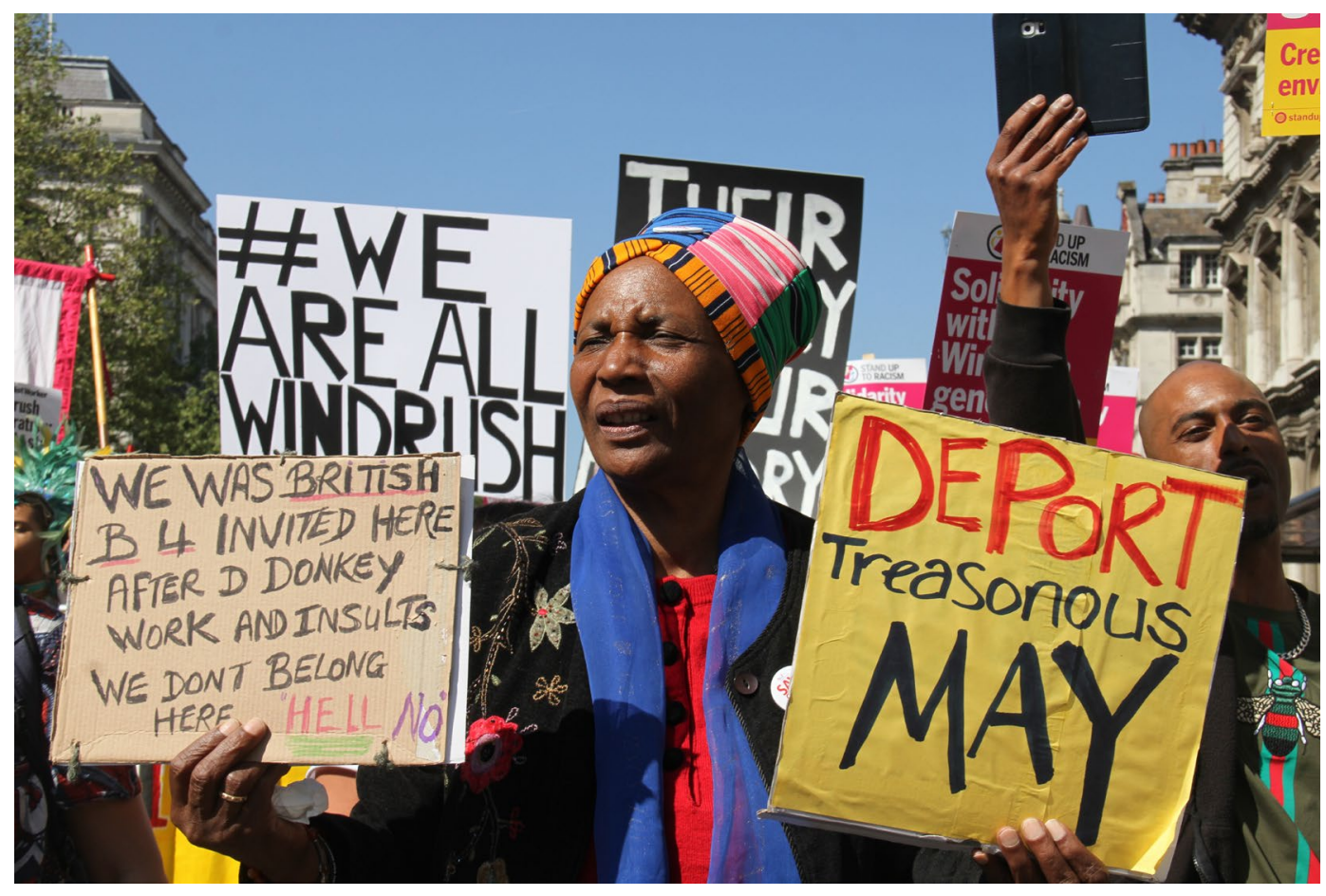

Figure 1. Whitehall, London, 5 May 2018: hundreds of people join the "March for Windrush" to protest against the "hostile environment." Photo David Mbiya/shutterstock.com

before seen. In 2019, now behind a hollow rhetoric of compensation and change, the government began placing immigration officers in public institutions. Satbir Singh, chief executive of the Joint Council for the Welfare of Immigrants, saw this as "Spreading the tentacles of this hostility ever deeper" (Savage and Cadwalladr 2019).

What was being enacted here exploited the twin characteristics of the border: a form of defense that can be moralized, and a violent act of "Othering" that deploys the dehumanizing and depersonalizing language of objectification and threat, in such words as "migrant" and "swarm" (BBC 2015), to render certain individuals beyond the compassion of the state. Willem Schinkel, in his analysis of state violence, observes an identical illusion: the state presents itself as enacting justice but it does so by simultaneously delegitimizing the citizen:

The state primarily directs the explicit use of its monopoly of violence towards its own subjects, more specifically towards those subjects not satisfyingly subjectified ... those subjects not properly "socialized", "adapted" or "integrated" ... But this view offers a one-sided sketch of the violence of the state. For since the state defines the borders of the legitimate, it is imprecise to conclude that internal state violence is merely reactive. The view of the violence of the state as being only reactive in fact legitimates the active forms of violence by the state by taking them to be induced by illegitimate forms of private violence (Schinkel 2010: 166-7).

Note that this use of objectifying categories has political efficacy that would be lost if these arguments were conducted using the specific examples of those vulnerable British citizens who were really the subject of the government's policies. (Of course, this same charge has been made 
against those museums that have tended to believe a certain level of professionalism and the possibility of neutral, objective truths are achieved through detached and depersonalizing acts of objectification and categorization (Knell 2021).) The government's use of categories and concepts, and its avoidance of the discussion of real lives, permitted it to argue that the fault was not with the policy but with the Windrush people for not having appropriate documentation. In television interviews, issuing apologies and feigning action, May remained resolute in her policy of exclusion, apparently believing that collateral damage was inevitable if the country was to be protected from the "scourge of immigration" (Marr 2018).

\section{Democracy and the Autonomous Museum}

In the context of border construction, othering, and state violence, and regardless of curatorial intent, exhibitions like that shown in Bedford were more than simply celebratory or acknowledging, or a means to fill a "compassion gap." As part of the distributed institutional fabric of the nation-state, the Higgins, and these other organizations, were countering a state's violence against its own citizens and dismantling a border at the very moment when the state sought to erect it. It was doing this not as a partisan political actor or as a political adversary but in its role as an institution that records and presents those empirical truths that form the ethical basis for the operation of a knowledge-based democracy. In a democracy, and in this overlooked role, the museum should be considered a constitutional requirement akin to an autonomous judiciary and free press. ${ }^{1}$

If this claim for an English provincial museum and a small temporary exhibition seems overstated, it can be proven if we apply the sharper lens of a museum in a democracy that has had a more troubled recent history. Such a museum can be found in Tirana, Albania: the National History Museum. Here in August 2012, under the heading "Border Killings," displays showed large photographs of the bodies of those young men, some in their teens, who had tried to escape the country in 1990 and were killed by forces of the collapsing communist dictatorship. This museum was here acting as a critical memory institution, keeping alive objective truths in a country that has often been subjected to unbending ideology. As a form of incontestable evidence, these photographs and associated objects countered the legacy of the dictatorship's elaborate political propaganda and misinformation, which were used at the time to control society but which also sought to shape future histories. Here the museum records actions at a territorial, political, and historical border, but it is also, as an institution, patrolling and guarding a border between a free, truth-based, democracy and violent, ideological, propaganda-based, authoritarianism. In this role, this fairly traditional, pragmatic, museum seems fundamentally important. With the communist regime overthrown, it was possible for the museum to compartmentalize, historicize, and pass judgment on the past, but it did so not by adopting a partisan political counterargument or position. It used instead that most powerful of museological resources: transparent material documentation. People died because of the hostile environment, just as they did at the Albanian border.

In 2019, a year after news of the Windrush scandal broke, the United Kingdom Parliament's Home Affairs Select Committee conducted an unrelated, but very pertinent, twenty-year review of the Macpherson Enquiry into mishandled police investigations of the raciallymotivated murder of a Black schoolboy, Stephen Lawrence, in London in 1993 (MacPherson 1999). Macpherson's most important conclusion had been to observe the dangers of "unwitting racism" in otherwise "good people and institutions." More than a decade earlier, in 1981, the Scarman Report into London's Brixton riots had detected the same phenomenon but had 
failed to recognize its consequences. Macpherson, however, saw it as manifesting what Stokely Carmichael and Charles V. Hamilton (1967) had termed "institutional racism," which, as they described in their book, Black Power: The Politics of Liberation in America:

... originates in the operation of established and respected forces in society. It relies on the active and pervasive operation of anti-black attitudes and practices. A sense of superior group position prevails: whites are "better" than blacks and therefore blacks should be subordinated to whites. This is a racist attitude and it permeates society on both the individual and institutional level, covertly or overtly (quoted in Macpherson 1999: 6.22).

This was not racism conducted as a matter of policy and practice but-as Police Commissioner Sir Paul Condon, who opposed the term, observed at the time-that which "can occur almost unknowingly, as a matter of neglect, in an institution" (Macpherson 1999: 6.25). Institutional racism arises where empowered professional communities build cohesion through shared acts of discrimination. A pernicious disease infecting an institution, it normalizes acts of bordering. Macpherson's charge that London's Metropolitan Police Service was institutionally racist was a wake-up call to British institutions more widely, including museums (Young 2003: 6; Tissier and Nathoo 2004; Mason 2004: 61). The 2019 review, however, concluded that organizations, including the Home Office and successive British governments, had been unwilling to understand, embrace, or implement this concept (Home Affairs Committee 2019). It saw the Windrush scandal and the government's hostile environment as manifestations of it (Muir 2018; Gentleman 2019a); officers in the Home Office seemed to be oblivious to the requirements of the Race Relations Act 1976, which recognized in law that racism can be enacted without racial motivation in seemingly neutral policy and practice that actually discriminates against groups with protected characteristics (Williams 2020: 114).

If, in the case of the Windrush scandal, institutions like the Home Office were a source of border construction, the 2019 select committee's review and Macpherson's inquiry exist as counterexamples that demonstrate the critical role played by autonomous state institutions in keeping the government executive and civil service in check. In doing so, they act to dismantle those borders that threaten the continued operation of a supposedly egalitarian democratic state. It was through these and other autonomous institutions, including cross-party committees and independent inquiries, that a pervasive culture of exclusion against the Windrush generation was revealed at the Home Office, which had made impossible demands of those it investigated; ignored and destroyed evidence; and refused to modernize its practices or protect citizens (Public Accounts Committee 2019; Israel 2019; Williams 2020). William Davies (2018) referred to this as "weaponising paperwork." These failings were similar to those that had arisen from institutional racism in the Metropolitan Police Service, but in the case of the Windrush scandal, journalistsin that other autonomous democratic institution, the "free press" - were rather doubtful that this was entirely "unwitting."

\section{Remembering Well}

Throughout the 2010s, anti-immigrant political discourse was expounded by the Conservative Party to see off the challenge of Nigel Farage's populist right-wing United Kingdom Independence Party (UKIP), immigration having risen dramatically under the previous Labour government (Watt and Wintour 2015; Migration Observatory 2019; Cangiano 2019). That Labour government had been taken by surprise by the wave of immigration from low wage economies in Central and Eastern Europe that followed the expansion of the EU between 2004 and 2007. It 
failed to find a positive discourse for the demographic and cultural changes that then began to take place in some of the least cosmopolitan communities in the United Kingdom. These communities, which had been ravaged by the Cameron government's policies of austerity and deregulation, had become pools of discontent receptive to the anti-immigration rhetoric of UKIP and the Conservatives. In 2017, twenty percent of the population of Boston, Lincolnshirewhich produced the country's strongest pro-Brexit vote-were migrants who had arrived in the previous decade (Fletcher 2017).

This reawakening of an anti-immigrant discourse had the same effect it had had previously, and famously following Conservative MP Enoch Powell's inflammatory "rivers of blood" speech of 1968: it brought racists out of their closets and back onto British streets (Savage 2018). It now became possible for public figures, such as Lord Andrew Green (2019), founder and chairman of the right-wing think tank Migration Watch UK, to publicly engage in racial conspiracy theories that suggested that the political left was working with non-white immigrants to overthrow the conservative establishment. He speculated that, "some projections show that the census category 'White British' will be a minority in England and Wales in about 50 years from now.' This was not an argument about numbers; it was about race and ethnicity. There was a startling rise in hate crime, particularly after the Brexit referendum - three quarters of which was race related (Home Office 2019). A central plank for pro-Brexit activists, rhetoric around immigration into communities with high levels of economic and educational deprivation fuelled the Brexit vote (Arnorsson and Zoega 2018). This was despite a lack of hard evidence showing that immigration had a net negative effect on the country, and a clear demonstration that the loss of migrants as a result of Brexit posed a real threat to the country's prosperity (Centre for Economic Performance 2016).

In December 2019, after years of inconclusive Brexit debate, a Boris Johnson-led Conservative government returned to power following a major swing amongst working class voters who responded to Johnson's promise to "get Brexit done." Drawing comparison to Donald Trump-even by Trump himself-Johnson had already shown a willingness to adopt authoritarian practices, for example, to prorogue (suspend) parliament to prevent the operation of democratic safeguards. He had been prevented from doing so by an independent judiciary, which deemed this act unlawful. Autocratic Russian President Vladimir Putin was at this time claiming that Western liberalism was coming to an end (Barber et al. 2019; see also, Albright 2018).

Some months earlier, in June 2019, the BBC aired public historian David Olusoga's (2019a, 2019b) film, The Unwanted: The Secret Windrush Files. It told an entirely different story of Windrush, one of racial prejudice stalking the corridors of power for seventy years. Olusoga argued that this had been concealed behind policies that appeared on the surface to be even-handed, but which were designed to adversely affect Black British citizens. Like May's hostile environment, these policies concealed invisible borders behind an illusion of fairness and moral purpose. He was not alone in observing this strange duality in British politics, but some saw the Brexit era as different:

Of course there were signs of state racism from the time of the first Immigration Act in 1962, but these were counterbalanced by anti-discrimination legislation and community programmes - and for a while the way was opened to a truly multicultural society, the foremost in Europe, and its exemplar. The difference today is that racism and xenophobia have become tied into the state itself, making nativism the state ideology and "take back control" its political culture (A. Sivanandan, quoted in Jon Burnett 2016 and 2017).

While it comes as no surprise to understand that racism existed and persisted in all sections of society and to some degree in all political parties in twentieth-century Britain, Olusoga's 
documentary was shown on a BBC neutered by government demands for apolitical and ahistorical "balance;" thus he spoke of a succession of governments engaging in covert acts of racial surveillance and policy formulation without pointing a finger at one side or the other. Of course, this long trajectory is important if we are to understand and learn from the past, but there is a problem with conflating the issues of 1948 with Britain in 2018, a country then possessing a richly multi-ethnic population and rigorously observed equality legislation. If it set the hostile environment in a longer context that helpfully showed the British were not as egalitarian as they liked to think they were (for which, see Webber 2018), it also made recent events look less exceptional, when in fact they were extraordinary and indicative of the parlous state of British democracy.

Unlike museums in one-party states (Knell 2021: 109-117), public institutions in Britain are obliged to remove themselves from partisan political views that might subvert their messages (see, for example, Her Majesty's Treasury 2019). For all that we might doubt the possibility of achieving this, museums have, nevertheless, developed a range of techniques to realize a semblance of neutrality and objectivity. To do this, they must negotiate a public record contaminated and confused by duplicitous political action, propaganda, obfuscation, and expediency that have no interest in truth. These seek to manifest power and image, both as a context for contemporary political action and to shape the historical record. This can be seen, for example, in Theresa May's attempts to construct a legacy that aided the misremembering of her calamitous time in office (Seldon 2019) and establish a positive association with the Windrush generation (see, for example, Busby 2019; Osborne 2019; May 2018; Savage 2020). Such actions live on to contest the truths that might be extracted from the past, and as such they act to prevent museums from seeking to construct a political narrative that truly represents cause and effect. Facts alone will not do this because they can always be subjected to political contestation. Indeed, arguably one of the reasons why the Windrush generation failed to enter the mainstream narrative of Britishness was that some contested a narrative that would permit a traditionally white, ethnocentric, definition to be replaced by one that embraced the truth of the country's long-established ethnic diversity.

Museums in Britain had, however, long ago oriented their looking away from that of state elites and towards the everyday experiences of the people. The rise of social history in the 1960s had had a transformative effect, and in the decades that followed spawned a new era of historical consciousness that set out to save the country's mills and country houses from demolition. Museums oriented themselves towards gender- and class-inclusive narratives of the lives of ordinary people as a replacement for the histories of great men that had earlier been in vogue. Inevitably and progressively, and under the influence of French social theory, this inclusivity was expanded and idealized. Generalized and normalized lives began to be replaced by real lives. While these narratives had their origins in progressive politics, they gained legitimacy in Britain through equalities and human rights legislation. This provided a platform for more activist approaches to museum representation that sought to proactively assault deeply ensconced social and cultural biases and discriminations (Message 2013; Janes and Sandell 2019). Museums became increasingly practiced in techniques that could be deployed to address social justice issues without being seen to adopt partisan political positions. Most important amongst these was quotation from the real world beyond the museum. I mean this both literally, such as by incorporating an external actor into an exhibition or event as a witness giving oral or written testimony, and metaphorically, by deploying an image or artifact capable of communicating the point without the museum needing to spell that point out in interpretation. Professionals often think that by doing this they are not themselves authoring the point being made, but of course they are through acts of editing and curating. These developments meant that museums were both attuned to the issues of the Windrush generation and practiced in ways they could offer support. 
Of all the Windrush exhibitions in 2018, perhaps the British Library's Windrush: Songs in a Strange Land was the most comprehensive and significant. It was developed as the Windrush scandal unfolded and dealt with the issues head on: "Welcomed by some as 'Sons of Empire.' Vilified by those spreading fears of a 'black invasion"' (British Library 2018b). The library also established a rich online repository of resources called Windrush Stories (British Library 2018c). The external lead for the exhibition, Colin Prescod, a sociologist and chair of the Institute of Race Relations and himself a migrant of the Windrush generation, contributed an article entitled "Why are people always banging on about racism?" which explained the team's "bold telling of the Windrush story"- "a deeper and darker Caribbean story"- that was no mere celebration:

Windrush: Songs in a Strange Land can therefore be read as a story of racism and resistance to racism. Running through the exhibition narrative is a kind of battle between oppression and liberation. And a paradox emerges. Out of the nightmare history of brutal enforced transportation, plantation slavery and racist-colonialism there is a striking back, expressed in an irrepressible imaginative, social, as well as intellectual flair that characterises these Caribbean people (Prescod 2018).

As an outsider brought into the library, Prescod becomes-to use the language above-a quotation from the real world. He could be imagined as embodying the subject and thus appears in much the same way as a museum might imagine an object to be inherently evidential. The difference, however, is that the object requires external rhetoric to become evidence; this was something Prescod could contribute himself. It meant this public institution could bear honest witness to the treatment of Black British citizens. The scandal could be confronted head-on:

It centred on the obscene insult to tens, then hundreds and eventually as it turned out thousands of Black British citizens, who were being routinely and variously summoned, arrested, locked up and threatened with deportation-many were actually wrongfully deported-because they were unable to provide a suspicious and hostile government Home Office with paper-evidence of their right to reside in Britain (Prescod 2018).

Through its deployment of authentic witnesses, experts, and cultural ambassadors, this, the national library, spoke truth to power. It erased a border that the government was inserting between a supposedly indigenous British population and those of its population who had migrant heritage, even if one or two generations ago, and even if they themselves were born in Britain and had worked their whole lives there. It strengthened the identity and visibility of the BritishCaribbean community in British culture, asserting its contribution as a rich and incontestable fact. It did so not by erecting a border between this community and the white British population but by assaulting an illegitimate border that still defended a view that the British were inherently white.

While the British Library's exhibition and associated web resources were an explicit return volley against the institutional racism still to be found in Britain in 2018, other exhibitions focused more on implicit demonstrations of legitimacy and worth simply by observing the cultural contribution of Black British communities. The power of the library's exhibition, as with "Border Killings" at the National History Museum in Tirana, rested on an institutional commitment to witnessed and evidence-based "real history." In both countries this relied upon the existence of autonomous institutions (pressure groups, think tanks, parliamentary committees, museums, libraries, universities, and so on).

Think tanks responded to the Windrush scandal by proposing ethical countermeasures based on rationalism and research data (Ballinger et al. 2019). The race equality think tank Runnymede Trust, for example, argued that migration, belonging, and empire should be taught more widely 
in British schools, where a quarter of students were from Black and minority ethnic (BME) backgrounds (McIntosh et al. 2019). Leaked conclusions from the independent report on the scandal by HM Inspector of Constabulary, Wendy Williams, also pointed to an institutional failure of memory; a failure to recall a history of changing migration patterns and citizenship rights (Williams 2020: 139). Kennetta Hammond Perry (2018), who works on state-sanctioned racial violence, argued for real histories of race in Britain, of the kind presented at the British Library:

Rather than continuing to pigeonhole Windrush into an ahistorical frame that uncritically props up a progressive image of a multicultural nation, this particular conjuncture summons our attention toward a more robust accounting of the broader terrain of disenfranchisement, injustice and disavowal that has historically shaped Black people's relationship to British citizenship and, by proxy, the British state.

\section{The Consequences of Truth-Denial and Forgetting}

Since institutional incompetence cannot be excused, just as ignorance is no defense under the law, a failure to represent the true history and diversity of the country today must be understood implicitly not just as a failure but as an "unwitting" act of institutional racism. It is within society's spaces of forgetting, such as the Home Office, that illegitimate borders are fabricated. Forgetting is both active and passive. The Home Office's active destruction of the only documentation that proved the right to residency of many of those who had arrived from the Caribbean preceded an accusatory government putting in place an unattainably high requirement for proof of residency that few of these citizens could meet (Gentleman 2018c). Forgetting also occurs naturally as the past recedes both in terms of its visibility and its contemporary relevance, but it is aided by carelessness that arises from resource starved, instrumentalist and editorial acts of curation, and by the museum's attachment to timeless monumentality, symbolism, reduction, neutrality, and canonicity (Wilson and Halle 1993). The museum, as the principal institution for rigorously and ethically knowing and remembering, has a critical role in ensuring a state operates on the basis of truth.

It is in this context that such Windrush exhibitions as the Higgins' "Paved with Gold": Bedford's Windrush Generation, the Museum of Oxford's The Windrush Years-Next Generations, Willesden Green's Windrush 70-Brent's Pioneering Windrush Generation, South Bank's Windrush: Portrait of a Generation, and the British Library's Windrush: Songs in a Strange Land should be viewed. They were not just time markers remembering a national anniversary, but rather acting to empower a social memory as a democratic assertion and, in the context of the scandal, a form of redress. The British Library ensured a permanent legacy. The Higgins did so too. It possessed a "Great Bedfordians" gallery that included "New Bedfordians" who contributed to the town in everyday roles and, amongst them, migrants. Other institutions seemed to quietly notice their own complicity in misremembering the past. There was, for example, a renewed push at the $\mathrm{BBC}$ to reflect the national demographic in its presenters; Black British actors also became de rigueur for companies expressing their brand in television advertising. These changes became more rapid and pervasive when the injustices of the Windrush scandal were joined by those that were the subject of the global Black Lives Matter campaign. This startling transformation in the broadcast media was not simply an act of rebranding; it proved the extent to which institutional racism permeated British society.

Here again, institutions beyond government were countering the government's acts of border creation-acts that had become much easier as ministers detached themselves from knowledge and expertise (Mance 2016; Carroll 2018; Sparrow 2018) and entered a world of myth, 
speculation, manipulation, populism, and propaganda that was post-fact, post-expert, posttruth (Kessler et al. 2019; Stephens 2019). If the border erected by the hostile environment was made possible by a disregard for truth, it was compounded by the politics of austerity and small state conservatism, which sought to deinstitutionalize the state in a "bonfire of the quangos" (Porter 2010) and replace it with an eighteenth-century view of the public realm, sustained by the volunteerism and patronage of "Big Society." Macpherson had delivered his report on the assumption that governments had a responsibility for ensuring an inclusive, cohesive, and compassionate state. That assumption, however, now seemed misplaced. The Cameron government had asserted individual wealth, freedom, and responsibility over the responsibilities of the state; the state was to be shrunk to 1930s levels of funding (Office of Budget Responsibility 2014). By 2018, the consequences could be widely observed in almost every aspect of British society and not least in rising inequality, poverty, and homelessness, and a crisis in social care (Kisby 2010; North 2011), with rough sleeping rising by 169 percent (Crisis 2018). Museums, which in the early 2000s had led efforts to build a more inclusive society, in the 2010s found themselves subjected to deep funding cuts. The state was withdrawing from its institutional responsibilities for knowledge and memory; society became rich in borders propagated by the neglect of the state, rising misinformation and dishonesty, divisive populism, lack of transparency, and so on. Out of a cloud of political posturing, real world consequences emerged, the most troubling being the Windrush scandal.

The Conservative government of Boris Johnson looked at public institutions differently, replacing independence and transparency with partisanship. It responded to the Black Lives Matter protests, for example, with a rapidly convened Commission on Race and Ethnic Disparities under the chairmanship of Tony Sewell, who had been criticized for having disregarded institutional racism (Sewell 2010). Critics believed that Johnson was simply attempting to bury the issue in interminable deliberations of a heavyweight institution, but the commission acted with haste, publishing its report early in 2021 (Sewell 2021). The speed at which it had arrived at its conclusions, however, soon found explanation in accusations that the commission had merely directed its evidence to support a priori positions, the principle one being to largely dismiss "institutional racism" as a cause of racial disparities in Britain. Shelter's (2021) Anti-Racism Steering Group argued that Sewell's report was itself an act of institutional racism. The UN Working Group of Experts on People of African Descent (Day et al. 2021) was particularly damning:

... mythical representation of enslavement is an attempt to sanitize the history of the trade in enslaved Africans ... that repackages racist tropes and stereotypes into fact, twisting data and misapplying statistics and studies into conclusory findings and ad hominem attacks on people of African descent ... cites dubious evidence to make claims that rationalize white supremacy ...

The heritage of this white supremacist rhetoric was at this time being protected by another wing of the Johnson administration, following statue toppling by Black Lives Matter protesters (Olusoga 2020; Boldrick 2021). Vowing to protect these statues in law, naively believing, or ideologically asserting, that the histories they record represent irrefutable and unauthored truths, Communities Secretary Robert Jenrick (2021) inadvertently demonstrated that institutional racism went right to the heart of government. Truth, it seemed, was merely an ideological position; it required no attachment to expertise, knowledge, or evidence.

The Windrush scandal and these attempts to manufacture ideological truths provide exemplary arguments for why we need museums and libraries to build a cohesive and effective state that has a non-partisan grip on reality. These arguments challenge a view, prevalent in recent decades and originating in the business-oriented methods of New Public Management with 
their concern for markets, management, and measurement, that the museum should be understood simply as a "creative industry." Just as economists argue that nations cannot wage war through delegation to private sector organizations, so other necessary performances of the state become troubled by the commercial motive. Pasts become forgotten or performed for profit or institutional success rather than to meet societal need. The Windrush scandal occurred through institutional neglect. For all that the museums and libraries acted to know and remember well in 2018, these institutions, too, had so often, and for too long, forgotten and failed to know.

In March 2020, Wendy Williams's (2020) independent report, Windrush Lessons Learned Review, was finally published. On that day, The Guardian-the paper whose investigative journalism had exposed the injustice-presented one final "exhibition" to mark the occasion: in its "Lambs to the slaughter': 50 lives ruined by the Windrush scandal," it gave a series of vignettes of British citizens victimized by the state (Gentleman 2020). As an example of truth telling, it precisely imitated the exhibit at the National History Museum in Tirana.

SIMON KNELL is Professor of contemporary museology at the School of Museum Studies, University of Leicester. His work, which has a global focus, has been concerned with knowledge communities, disciplinarity, and the object/museum. His most recent contributions have sought to conceptualize the "global contemporary," "contemporary museology," and the "contemporary museum." He has published more than twenty books, his most recent being National Galleries: The Art of Making Nations (Routledge, 2016); The Contemporary Museum: Shaping Museums for the Global Now (Routledge, 2019); and The Museum's Borders: On the Challenge of Knowing and Remembering Well (Routledge, 2021).

\section{NOTE}

1. My point here is different from late twentieth-century narratives in the museum studies and history of science literatures that interpreted these institutions as engaged in social control for the purposes of managing democracy (e.g. Shapin and Barnes 1977; Hooper-Greenhill 1989: 63; Bennett 1995). Museums have been much discussed in relation to the democratization of culture and participative democracy (for example, Chakrabarty 2002; Message 2007; Cameron and Deslandes 2011).

\section{REFERENCES}

Albright, Madeleine. 2018. Fascism: A Warning. New York: Harper Collins.

Arnorsson, Agust and Gylf Zoega. 2018. "On the Causes of Brexit." European Journal of Political Economy 55: 301-23.

Ballinger, Steve, Sunder Katwala, Jill Rutter, and James Kirkup. 2019. Immigration After May. London: British Future.

Barber, Lionel, Henry Foy and Alex Barker. 2019. "Vladimir Putin Says Liberalism Has 'Become Obsolete." Financial Times, 28 June.

Bennett, Tony. 1999. The Birth of the Museum: History, Theory, Politics. London: Routledge.

Boldrick, Stacy. 2021. Iconoclasm and the Museum. London: Routledge.

Brinkhurst-Cuff, Charlie. 2018. Mother Country: Real Stories of the Windrush Children. London: Headline. 
British Broadcasting Corporation (BBC). 2015. "David Cameron Criticised over Migrant 'Swarm' Language.” BBC News, 30 July. BBC. https://www.bbc.co.uk/news/uk-politics-33716501 (accessed 30 April 2020).

British Broadcasting Corporation (BBC). 2018. "Windrush victims detained 'unlawfully' by Home Office." BBC News, 29 June. BBC. https://www.bbc.co.uk/news/uk-politics-44651105 (accessed 26 April 2021).

British Library. 2018a. “Timelines: sources from history, Windrush: post-war immigration." British Library. https://www.bl.uk/learning/timeline/item107829.html (accessed 26 April 2021).

British Library. 2018b. "Windrush: Songs in a Strange Land (exhibition publicity)." British Library. https://www.bl.uk/events/windrushsongs-in-a-strange-land (accessed 1 November 2019).

British Library. 2018c. "Windrush Stories." British Library. https://www.bl.uk/windrush (accessed 1 December 2019).

Burnett, Jon. 2016. Racial Violence and the Brexit State. London: Institute of Race Relations.

Burnett, Jon. 2017. "Racial Violence and the Brexit State." Race \& Class 58 (4): 85-97.

Busby, Mattha. 2019. "May's Plan for Windrush Memorial at Waterloo met with 'Disgust." The Guardian, 22 June.

Cameron, David. 2011a. "PM’s Speech at Munich Security Conference." 5 February. UK Government. https://www.gov.uk/government/speeches/pms-speech-at-munich-security-conference (accessed 26 April 2021).

Cameron, David. 2011b. “On Immigration: Full Text of the Speech.” The Guardian, 14 April.

Cameron, Fiona and Anne Deslandes. 2011. "Museums and Science Centres as Sites for Deliberative Democracy on Climate Change." Museum \& Society 9 (2): 136-53.

Cangiano, Alesso. 2019. “The Impact of Migration on UK Population Growth.” Migration Observatory Briefing, 18 December. https://migrationobservatory.ox.ac.uk/resources/briefings/the-impact-ofmigration-on-uk-population-growth/ (accessed 27 April 2021).

Carmichael, Stokely and Charles V. Hamilton. 1967. Black Power: The Politics of Liberation in America. New York: Random House.

Carroll, Rory. 2018. "Karen Bradley Admits Ignorance of Northern Ireland Politics." The Guardian, 7 September.

Centre for Economic Performance. 2016. Brexit 2016: Policy Analysis from the Centre for Economic Performance. London: London School of Economics and Political Science.

Chakrabarty, Dipesh. 2002. "Museums in Late Democracies." Humanities Research 9 (1): 5-12.

Crisis. 2019. Homelessness Monitor: England 2018. https://www.crisis.org.uk/ (accessed November 2019).

Davies, William. 2018. "Weaponising Paperwork." London Review of Books 40 (9).

Day, Dominique, Ahmed Reid, Subelo Gumedze, Michal Balcerzak, and Ricardo A. Sunga III. 2021. "UN Experts Condemn UK Commission on Race and Ethnic Disparities Report.” UN Human Rights, https://www.ohchr.org/EN/NewsEvents/Pages/DisplayNews.aspx?NewsID=27004\&LangID=E (accessed 29 April 2021).

Fletcher, Nicholas. 2017. "New Figures Reveal Scale of Immigration in these Seven Areas of Lincolnshire over the Last Decade." Lincolnshire Live, 24 July.

Gentleman, Amelia. 2018a. "IIve Been Here for 50 years': The Scandal of the Former Commonwealth Citizens Threatened with Deportation." The Guardian, 21 February.

Gentleman, Amelia. 2018b. "Man Living in UK for 56 years Loses Job over Immigration Papers." The Guardian, 9 April.

Gentleman, Amelia. 2018c. "Home Office Destroys Windrush Landing Cards, Says Staffer." The Guardian, 17 April.

Gentleman, Amelia. 2019a. "MPs Refer Home Office to Equalities Watchdog over Windrush Scandal." The Guardian, 1 May.

Gentleman, Amelia. 2019b. The Windrush Betrayal. London: Guardian Faber.

Gentleman, Amelia 2020. “Lambs to the Slaughter': 50 Lives Ruined by the Windrush Scandal." The Guardian, 19 March. 
Green, Lord Andrew. 2019. “Labour's Immigration Policy is a Threat to the Country's Future." Conservative Home, 25 November. https://www.conservativehome.com/platform/2019/11/andrew-green -labours-immigration-policy-is-a-threat-to-the-countrys-future.html (accessed 26 April 2021).

Hammond Perry, Kennetta. 2018. "Undoing the Work of the Windrush Narrative." History Workshop, 11 September. http://www.historyworkshop.org.uk.

Her Majesty’s Treasury. 2019. Managing Public Money. UK Government. https://www.gov.uk/ government/publications

Hill, Amelia. 2017. “'Hostile Environment': The Hardline Home Office Policy Tearing Families Apart.” The Guardian, 28 November.

Home Affairs Committee. 2019. The Macpherson Report: Twenty Years On Inquiry, oral evidence, 18 June.

Home Office. 2019. Hate Crime, England and Wales, 2018/19, 16 October.

Hooper-Greenhill, Eilean. 1989. “The Museum in the Disciplinary Society." In Museum Studies in Material Culture, ed. Susan Pearce, 61-72. Leicester: Leicester University Press.

Israel, Simon. 2019. "Windrush Scandal: Home Office 'Reckless' and 'Defensive', Leaked Review Finds." Channel 4 News, 27 June. https://www.channel4.com/news/windrush-scandal-home-office-reckless -and-defensive-leaked-review-finds (accessed 27 June 2019).

Janes, Robert R. and Richard Sandell (eds). 2019. Museum Activism. London: Routledge.

Jenrick, Robert. 2021. "New Legal Protection of England's Heritage." UK Government. https://www.gov. uk/government/news/new-legal-protection-for-england-s-heritage

Kentish, Benjamin. 2018. “Theresa May Was Aware and Not Opposed to 'Go Home’ Immigration Vans, Suggests Home Office Statement." The Independent, 19 April.

Kessler, Glenn, Salvador Rizzo and Meg Kelly. 2019. "President Trump Has Made 13,435 False or Misleading Claims over 993 Days." The Washington Post, 14 October.

Kirkup, James and Robert Winnett. 2012. “Theresa May Interview: 'We're Going to Give Illegal Migrants a Really Hostile Reception."' The Telegraph, 25 May.

Kisby, Ben. 2010. “The Big Society: Power to the People?” Political Quarterly 81 (4): 484-91.

Knell, Simon. 2021. The Museum's Borders: On the Challenge of Knowing and Remembering Well. London: Routledge.

Liberty. 2019. A Guide to the Hostile Environment. London: Liberty.

Macpherson, Sir William. 1999. The Stephen Lawrence Enquiry. London: Report of the Enquiry.

Mance, Henry. 2016. "Britain Has Had Enough of Experts, Says Gove." Financial Times, 3 June.

Marr, Andrew. 2018. "Interview with Theresa May, 30 September 2018." The Andrew Marr Show. https:// www.youtube.com/watch? $\mathrm{v}=\mathrm{rCwRz} 4 \mathrm{vuC9k}$ (accessed 26 April 2021).

Mason, Rhiannon. 2004. "Conflict and Complement: An Exploration of Discourses Informing the Concept of the Socially Inclusive Museum in Contemporary Britain." International Journal of Heritage Studies 10 (1): 49-97.

May, Theresa. 2018. "Black History Month Message from the Prime Minister Theresa May." Black History Month Magazine, 1 October.

McDowell, Linda. 2018. "How Caribbean Migrants Helped to Rebuild Britain." British Library. https:// www.bl.uk/windrush/articles/how-caribbean-migrants-rebuilt-britain\# (accessed 26 April 2021).

McIntosh, Kimberly, Jason Todd and Nandini Das. 2019. Teaching Migration, Belonging and Empire in Secondary Schools. Liverpool/London: TIDE/Runnymede Trust.

Message, Kylie. 2007. "Museums and the Utility of Culture: The Politics of Liberal Democracy and Cultural Well-Being." Social Identities 13 (2): 235-56.

Message, Kylie. 2013. Museums and Social Activism: Engaged Protest. London: Routledge.

Migration Observatory. 2019. "EU migration to and from the UK," https://migrationobservatory.ox.ac.uk/ resources/briefings/eu-migration-to-and-from-the-uk/ (accessed November 2019).

Muir, Hugh. 2018. “The Windrush Scandal is Institutional Racism, Pure and Simple." The Guardian, 30 April.

North, Peter. 2011. "Geographies and Utopias of Cameron’s Big Society." Social \& Cultural Geography, 12 (8): 817-27. 
Office of Budget Responsibility. 2014. "Economic and Fiscal Outlook, December 2014." https://obr.uk/ efo/economic-fiscal-outlook-december-2014/ (accessed October 2019).

Olusoga, David. 2019a. The Unwanted: The Secret Windrush Files. London: Uplands Television.

Olusoga, David. 2019b. "Windrush: Archived Documents Show the Long Betrayal.” The Guardian, 16 June.

Olusoga, David. 2020. “The Toppling of Edward Colston's Statue is Not an Attack on History. It is History." The Guardian, 8 June.

Osborne, Samuel. 2019. "Theresa May Accused of "Arrogance" over Windrush Memorial Plans as Campaigners Demand End to Hostile Environment." The Independent, 22 June.

Porter, Andrew. 2010. "Quango Cuts: 177 Bodies Scrapped Under Coalition Plans." Telegraph, 24 September.

Prescod, Colin. 2018. “'Why Are People Always Banging on About Racism?' Reflections on Windrush: Songs in a Strange Land, Windrush Stories." British Library. https:// www.bl.uk/windrush/articles/ why-are-people-always-banging-on-about-racismreflections-on-windrush-songs-in-a-strange-land (accessed December 2019).

Public Accounts Committee. 2019. Windrush Generation and the Home Office Inquiry, 6 March.

Savage, Michael. 2018. "Fifty Years On, What is the Legacy of Enoch Powell's "Rivers of Blood" Speech?" The Guardian, 15 April.

Savage, Michael. 2020. “Theresa May’s Social Injustice Office ‘Doesn’t Exist—and Never Will?' The Guardian, 21 March.

Savage, Michael and Carole Cadwalladr. 2019. "Revealed: How Home Office Hires Out Staff to Hunt Migrants." The Guardian, 16 February.

Schinkel, Willem. 2010. Aspects of Violence: A Critical Theory. Basingstoke: Palgrave Macmillan.

Seldon, Anthony. 2019. May at 10. London: Biteback Publishing.

Sewell, Tony. 2010. "Master Class in Victimhood." Prospect Magazine, 22 September.

Sewell, Tony. 2021. Commission on Race and Ethnic Disparities: The Report. https://assets.publishing. service.gov.uk/government/uploads/system/uploads/attachment_data/file/974507/20210331_-_ CRED_Report_-_FINAL_-_Web_Accessible.pdf

Shapin, Steven and Barry Barnes. 1977. "Science, Nature and Control: Interpreting Mechanics Institutes." Social Studies in Science 7: 31-74.

Shelter. 2021. "The Sewell Report: An Example of Institutional Racism." Shelter. https://blog.shelter.org.uk/ 2021/04/the-sewell-report-an-example-of-institutional-racism/ (accessed 29 April 2021).

Sparrow, Andrew. 2018. "All at Sea: Raab’s Ignorance of Dover-Calais Stuns Critics." The Guardian, 8 November.

Stephens, Philip. 2019. “Boris Johnson’s Lies Are Plunging Britain into a Dark Morass." Financial Times, 19 September.

Taylor, Diane. 2018. "UK Removed Legal Protection for Windrush Immigrants in 2014." The Guardian, 16 April.

Tissier, Damian and Samir Singh Nathoo. 2004. Black and Minority Ethnic Engagement with London's Museum: Telling It Like It Is: Non-user Research. London: Strategic Urban Futures.

Travis, Alan. 2013. “Go home’ Vans Resulted in 11 People Leaving Britain, Says Report.” The Guardian, 31 October.

Watt, Nicholas and Patrick Wintour. 2015. "How Immigration Came to Haunt Labour: The Inside Story." The Guardian, 24 March.

Webber, Frances. 2018. The Embedding of State Hostility: A Background Paper on the Windrush Scandal. London: Institute of Race Relations Briefing Paper 11.

Williams, Wendy. 2020. Windrush Lessons Learned Review. London: UK Government Home Office.

Wilson, Fred and Howard Halle. 1993. "Mining the Museum." Grant Street 44: 151-72.

Young, Lola. 2003. "Rethinking Heritage: Cultural Policy And Inclusion." In Museums, Society, Inequality, ed. Richard Sandell, 203-12. London: Routledge. 